\title{
Education Innovation: The Implementation of Smart Pad Classroom in the Chinese Context
}

\author{
Yiyang $\mathrm{Yu}^{1, *}$ \\ ${ }^{1}$ School of Management, University College London, London, WC1E 6BT, United Kingdom \\ *Corresponding author. Email: zceiyuc@ucl.ac.uk
}

\begin{abstract}
The rapid development of educational technology facilitates learning efficiency and enhances the availability of digital resources to create immersed personalized learning experience for learners. The Chinese education system has been transforming from a traditional blackboard classroom to normalizing ed-tech for quotidian learning. This paper reviews the Chinese system's distinctive features and examines the significance of Gao Kao and teacher's center pedagogy. Furthermore, the current status of technology usage and potential barriers for integration has been analyzed, and a detailed assessment of the Smart Pad as an innovative tool has been provided. Finally, discuss the challenges for Smart Pad integration and requirement for future research.
\end{abstract}

Keywords: Smart Education, Education Technology, Personalized learning, Smart Pedagogy, Chinese context

\section{INTRODUCTION}

Smart Education as a new phenomenon to meet the needs of the digital society has begun to attract more researchers' attention. The concept extends from e-learning as it changes the aspects of the educational process through innovative technologies to stimulate learner-centric and provide personalized learning services to enhance the flexibility of learning [1].

The Chinese education system has been criticized for being too rigid and unresponsive to individual needs [2]. In response to the requirements for education innovation, the Chinese Ministry of Education has initiated an intelligent education plan [3]. Educational Smart Pad has been embedded into primary and secondary classrooms to provide students with a personalized learning environment, increase class-based interaction, and enhance students learning motivation. However, there is a limited understanding of Educational Smart Pad, as It differs from other multi-purpose technology devices such as smartphones and iPads. Smart Pad consists of a comprehensive Learning Management System, providing the fundamental communication functions and allowing teachers to upload lecture slides, assign assessments, and receive student performance feedback instantly. In contrast, students are prohibited to download other apps to avoid distraction. By utilizing educational big data, Smart Pad can collect, analyse and evaluate data relevant to learning. As an innovative educational approach, the Smart Pad classroom will undoubtfully cause significant changes in the overall education system, impacting pedagogy, assessment and teacher's role.

In the following sections, the unique features of Chinese Education are depicted; the integration of technology to facilitate Education is reviewed; Furthermore, the perspective of Educational Technology to ameliorate the obstacles within traditional Chinese Education are presented. Finally, suggestions for future research are proposed to enhance the understanding within the scope.

\section{CHARACTERISTICS OF CHINESE EDUCATION SYSTEM}

\subsection{The Significance Of Gao Kao}

With limited top universities slots for a vast population, Chinese Education has adopted the National College Entrance Examination (Gao Kao) to provide students equal opportunities to go forward with their education. However, there is a growing dissatisfaction with China's examination system. Parents are concerned with students' health as Gao Kao requires long hours of 
test preparation, taking away students' time for sleep and exercise. The validity of student achievement scores is also being questioned as Chinese students have lower performance on problem-solving and critical thinking tasks [4]. Moreover, the significant importance of Gao Kao perceived by Chinese society puts tremendous pressure on students, as those who fail to achieve good results will shame the family. Some students have committed suicide after failing this 'momentous' test [5].

On the other hand, the Chinese Education System presents major inequality problems. The uneven resource allocation among urban and rural regions suggests students from higher socioeconomic backgrounds and large cities will have more education resources with higher quality teaching result in a better chance for success on Gaokao.

\subsection{Teacher-centered Pedagogy}

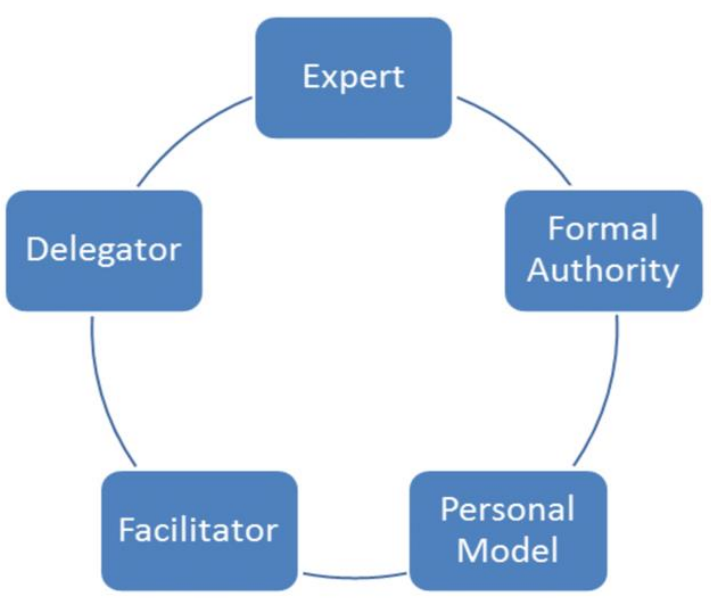

Figure 1. Five Teaching Styles

The Chinese culture is high on power distance, suggesting students are more passive and reluctant to participate in interactive activities actively [6]. Also, the competitive nature of Chinese Education often requires teachers to regard themselves as the expert to transmit knowledge and formal authority to set classroom standards. In comparison to Western teachers who sees themselves more of facilitators, to develop students for independent action and responsibility.

When comparing the Chinese education system to education in Western countries, [7] found that teachers who hold constructivist educational beliefs are more likely to use a student-centered approach. With the Chinese tradition based on Confucius's philosophy emphasizing group-based, teacher-centered pedagogy, Chinese teachers tend to express more doubts about constructivist principles and ICT application principles. Unlike western countries, technology has not been viewed as foundational or necessary in day-to-day education.

\section{REVIEW OF TECHNOLOGY INTEGRATION IN CHINESE EDUCATION}

\subsection{Thrive Of Chinese Ed-Tech Industry}

Chinese Education is shifting the educational system's focus with a recent drive to educate students through active engagement instead of lecturing. The Chinese Ministry of Education provided funding and resources to increase information and communication technology usage in schools. The government has also strongly requested that all teachers participate in professional development activities about effectively integrating technology into their classrooms. With the outbreak of the Covid-19 pandemic causing a digital shift in Education, the Chinese EdTech companies continue to proliferate as the state council invests $\$ 6$ billion into Educational AI technology [8]. Primary and secondary schools in China have started to normalize the use of Smart Pad in classrooms to establish more engaging classroom group activities and facilitate understanding of learning content.

\subsection{Barriers Of Classroom Technology Integration}

Despite access to technology, increased training for teachers, and a favourable policy environment, high-level technology use is still surprisingly low [9]. Although there is increased access to adequate educational technologies in their classrooms, Chinese teachers were not designing learning activities that allowed students to participate in technology-rich activities.

The barriers for classroom ICT integration have been categorized into external and internal barriers [10]. Previous studies have identified limited technology resources as a main external barrier for classroom integration since technology resources are costly and need to be continually updated [11]. Teachers may struggle to keep up to date with technological resources and be reluctant to invest the necessary time learning new technologies. Meanwhile, administrators experience difficulties justifying funding for the new resources when existing technologies are not being utilized due to a lack of training. The government sensed the importance of access to the Internet for all schools; however, restrictions were put in place as the government concerns what students could be exposed to online. Dealing with inappropriate student behaviour on the Internet and reviewing acceptable use policies affecting appropriate Internet is crucial.

On the other hand, teachers play an essential role in impacting the benefits of technology-embedded classrooms. Teachers may learn the technology as knowledge but choose to not believe in its usefulness. Ertmer suggested that teachers use technology in 
coherent ways with their personal beliefs about curriculum and instructional practice [12]. Teachers are likely to think about technology the same way they think about other teaching methods and respond to new instructional situations by relying on previous beliefs and experiences.

Zhu, Valcke and Schellens have identified three strategies to promote change in teachers' beliefs, including personal experiences, vicarious experiences, and social-cultural influences [13]. Govender suggested that teachers are more likely to adopt technology if the usage does not change their pedagogy and the new technology is more effective than traditional methods [14]. Therefore, it may be more productive to start with simple use when implementing new technology than expecting teachers to achieve high-end instructional goals. If teachers feel pressured to change their pedagogy to accommodate new technologies, they are more likely to resist adopting technology altogether.

Furthermore, Abdallah indicates successful ICT integration depends upon the development of a shared vision [15]. Collaboration between school environments, administrators, and staff is essential for successful technology integration into the curriculum. Schools and institutions need to provide ample time and support for teachers to interact and help each other explore new technologies and new technologies pedagogies. School leaders should make a substantial effort to ensure that all people are involved in the decision-making processes, with administrators, teachers and students addressing how technologies will be incorporated into the instructional environment. Moreover, schools could adopt a small community of practice allowing teachers to explore the full potential of Smart Pad jointly, along with ongoing technical and pedagogical support to develop teachers' confidence and competence.

\section{EDUCATIONAL SMART PAD AS INNOVATIVE EDUCATION METHODS}

\subsection{Smart Pad Objectives}

With the $5 \mathrm{G}$ enhancing the importance of data-driven decision-making, there has been increased attention on utilizing big data to enhance smart learning outcomes [16]. Through learning analytics to collect, analyse and evaluate data relevant to learning, Smart Pad can improve the educator's instruction design and learning efficiency. With the personalized context-aware recommendation learning system, Smart Pad provides students with learning materials and exercises based on previous performance and individual context. While different brands may differ in specific functionalities, the core features of the Smart Pad are practically identical, including a learning management system enabling live communication, displaying students' achievement, discussion group, assignments and reports. All aim to enhance personalized learning and encourage classroom collaboration.

\subsection{Smart Pad Pedagogy}

The Smart Pad classroom implements a similar pedagogy as the flipped classroom [17]. Students will self-study traditional lecture contents pre-class while spending the in-class period participating in classroom activities. Previous studies have suggested that the flipped learning model allows students to be more prepared and improves their willingness and confidence to engage in classroom activities. Also, the SmartPad will record students' current learning status, including reading time, answering accuracy, question attempts stored in personal learning records. In response, teachers can collect students' learning information at different times and produce student portfolios. Teachers can receive instant students' performance feedback on Smart Pad to initiate classroom discussions specifically targeting poorly answered questions. Through analyzing student data from pre-lesson reports, teachers can design more applicable and personalized exercises to solidify and enhance students' knowledge learned in class [18]. Within the Smart Pad classroom, the traditional role of teachers as informants will change to become students' facilitators and motivators.

\subsection{Smart Pad On Education Inequity}

On the other hand, the three steps of education equity include fair starting point, fair process and fair outcome. Smart Pad also serves to alleviate the problem of education inequity by targeting different categories of education inequity. Smart Pad companies have been providing schools in rural areas the hardware equipment, allowing them access to the resource library created by prestigious teachers from urban areas [19]. The access to massive open resources allows rural students to enjoy the same high-quality lecture and exam preparation materials as urban schools. Moreover, Smart Pad has been served as a medium to foster co-Teaching between rural and urban schools. Schools from rural regions will be connected to urban schools' classrooms, having the class with urban students and receiving lectures from more experienced urban teachers. The implementation of Smart in high schools in Lixian has achived a record high of 20 students admitted to university [20].

Moreover, Chinese education has been focused on individual competition, and students develop the mentality that other people's indicates a failure of oneself. When students achieve poor examination results, they tend to attribute the failure to external factors such as the environment and bad luck instead of reflecting on themselves [21]. Moreover, Chinese 
teachers favour excellent academic performance students and pay significant attention to poor performance students. It is common for Chinese schools to allocate students to different classes based on their study performance. While top students are being taught with elite teachers, gaining more confidence through positive feedback from teachers, poor students may receive less attention, and more criticism leads to self-questioning and losing motivation to learn. The grouping function on Smart Pad allows students to be assigned to random groups for the semester based on their previous performance. Each group will consist of students from various levels of learning abilities, allowing those top to play the role of instructor and guide the less well-performed teammates. During collaborative learning, helping others helps top students enhance their knowledge of the content. In contrast, poor students will be more willing to learn and contribute, accounting for the team's honors.

\subsection{Social Response Towards Smart Pad}

Despite the promising potential of SmartPad to achieve Smart Education objectives, the implementation of Smart Pad in the classroom still faces obstacles. CCTV has reported that schools were forcing parents to purchase over-priced Smart Pad under the claim of promoting Smart Education [22]. The disputes have prohibited the popularise of Smart Pad in the classroom.

As a critical facilitator of Smart Pad usage, it is crucial to evaluate how teachers' attitudes impact the successful integration of Smart Pad to achieve its value entirely. On the other hand, students at the center of Smart Education have received minor concerns about their education technology needs. As digital native learners, students are constantly adopting innovative technologies to fulfil their learning needs making it critical to evaluate the usefulness of Smart Pad from students' viewpoint. In addition, various citeria could be used to further evaluate the effectiveness and efficiency of education apps. The interactivity of educational app is crucial to motivate students engagement and provide incentives to users. Apps with personalised features with customized options, cooperation and competition functionalities can significantly increase students engagement and provide incentives to users. Also, Smart Pad's content should also be strongly relevant to the students' school curriculum, enabling them to embed acquired knowledge into practical applications. Finally, as contesting parents consider Smart Pad to be overpriced, it is necessary to assess Smart Pad's economic efficiency focuses on students view towards Smart Pad's price linked to its quality and appropriate to buy.

\section{CONCLUSION}

This literature has provided a preliminary study on the potential of the Smart Pad classroom as an innovative education method to promote personalized learning and mitigate education inequality in the context of China. As an innovative education method, the Smart Pad classroom requires extensive future research to explore its implementation and evaluate its effectiveness to meet the objectives of Smart Education.

The successful integration and full potential of the Smart Pad classroom will be dependent on students' and teachers' perceptions towards this new classroom model. Furthermore, the effectiveness is built upon designers' comprehension and integrative usage of Smart Pads functionalities, learner features and supportive strategies to achieve the educational potential and effectiveness.

The potential barriers and difficulties for teachers to implement technology previously defined within the classroom tend to be outdated and require further research under the context of the SmartPad classroom. Smart Pad integration, as a complex system, may necessitate more effort from teachers than simple technological applications. Although previous studies have neglected the intricate process in which teachers struggle to implement a foreign and potentially disruptive innovation into their familiar environment. Further research is needed to understand why teachers are not utilizing Smart Pads to achieve the goals visualized by the Smart Education framework and investigate further identify how to introduce Smart Pad as a technology that can support teachers' most immediate needs.

Moreover, previous studies have focused on teacher profiles towards the adoption of educational technology in schools. However, students as the center of the Smart Education framework, their perceptions are often overlooked. Little is known on the quality and quantity of students' interactivity with classroom technology. A greater understanding of different factors affecting students' perception of Smart Pad classroom would shed more light on evaluating whether Smart Pad classroom is a feasible way to achieve Smart Education.

\section{REFERENCES}

[1] Zhu, Z., Yu, M. and Riezebos, P., 2016. A research framework of smart education. Smart Learning Environments, 3(1).

[2] Mottus, A., Kinshuk, Chen, N., Graf, S., Alturki, U. and Aldraiweesh, A., 2018. Teacher facilitation support in ubiquitous learning environments. Technology, Pedagogy and Education, 27(5), pp.549-570. 
[3] Xinhuanet.com. 2021. CCPC publication <Chinese Education Modernisation Plan 2035>. [online] Available at: <http://www.xinhuanet.com/politics/2019-02/23/c_ 1124154392.htm> [Accessed 10 October 2021].

[4] Rogers, K., 2009. A preliminary investigation and analysis of student learning style preferences in further and higher education. Journal of Further and Higher Education, 33(1), pp.13-21.

[5] Press, Z., 2021. China's Cutthroat School System Leads to Teen Suicides. [online] WSJ. Available at: <https://www.wsj.com/articles/BL-CJB-22191> [Accessed 27 September 2021].

[6] Sang, G., Valcke, M., van Braak, J., Tondeur, J. and Zhu, C., 2010. Predicting ICT integration into classroom teaching in Chinese primary schools: exploring the complex interplay of teacher-related variables. Journal of Computer Assisted Learning, 27(2), pp.160-172.

[7] Sang, G., Valcke, M., Braak, J. and Tondeur, J., 2010. Student teachers' thinking processes and ICT integration: Predictors of prospective teaching behaviors with educational technology. Computers \& Education, 54(1), pp.103-112.

[8] Shleifer, E., 2021. Quarantined: China's Online Education in the Pandemic. [online] Thediplomat.com. Available at: <https://thediplomat.com/2020/03/quarantined-chin as-online-education-in-the-pandemic/> [Accessed 29 September 2021].

[9] Hwang, G. and Fu, Q., 2020. Advancement and research trends of smart learning environments in the mobile era. International Journal of Mobile Learning and Organisation, 14(1), p.114.

[10] Ijabah, N., 2018. Teachers' Perceptions and Barriers on Creating Technology-enhanced and Student-centered Classroom. Contemporary Social Sciences, 27(1), pp.33-48.

[11] Leem, J. and Sung, E., 2018. Teachers' beliefs and technology acceptance concerning smart mobile devices for SMART education in South Korea. British Journal of Educational Technology, 50(2), pp.601-613.

[12] Ertmer, P., 2005. Teacher pedagogical beliefs: The final frontier in our quest for technology integration?. Educational Technology Research and Development, 53(4), pp.25-39.

[13] Zhu, C., Valcke, M. and Schellens, T., 2010. A cross-cultural study of teacher perspectives on teacher roles and adoption of online collaborative learning in higher education. European Journal of Teacher Education, 33(2), pp.147-165.

[14] Govender, D., 2013. Using perceptual control theory to analyse technology integration in teaching. The Journal for Transdisciplinary Research in Southern Africa, 9(1).

[15] Abdallah, A., 2018. PARENTS PERCEPTION OF E-LEARNING IN ABU DHABI SCHOOLS IN UNITED ARAB EMIRATES. IJASOSInternational E-journal of Advances in Social Sciences, pp.30-41.

[16] Daniel, B., 2014. Big Data and analytics in higher education: Opportunities and challenges. British Journal of Educational Technology, 46(5), pp.904-920.

[17] Davies, R., Dean, D. and Ball, N., 2013. Flipping the classroom and instructional technology integration in a college-level information systems spreadsheet course. Educational Technology Research and Development, 61(4), pp.563-580.

[18] McSweeney, E., 2021. How AI eases teachers' heavy workloads. [online] Ft.com. Available at: <https://www.ft.com/content/da3a9bac-3e0a-11eab84f-a62c46f39bc2> [Accessed 2 October 2021].

[19] Vandenberg, L., 2021. EdTech in Rural China. [online] Thediplomat.com. Available at: $<$ https://thediplomat.com/2020/12/edtech-in-rural-c hina/> [Accessed 10 October 2021].

[20] Bianchi, N., 2021. Reducing rural-urban education gap through computer-assisted learning | VOX, CEPR Policy Portal. [online] Voxeu.org. Available at:

<https://voxeu.org/article/reducing-rural-urban-edu cation-gap-through-computer-assisted-learning > [Accessed 7 October 2021].

[21] Zhao, X., 2016. Educating Competitive Students for a Competitive Nation: Why and How Has the Chinese Discourse of Competition in Education Rapidly Changed Within Three Decades. Berkeley Review of Education, 6.

[22] CN, G., 2021. [Focus Report: Parents forced to buy tablets!]. [online] Sohu.com. Available at: <https://www.sohu.com/a/426405435_162758> [Accessed 8 October 2021]. 